\title{
Dutch Classicism in Europe
}

At first glance, the Golden Age and classicism would not seem to be an obvious pairing. Of all the art produced in the Dutch Republic during the seventeenth century, the works which are viewed as paeans to the everyday are the ones that generally receive the most attention. Biblical and mythological subjects are framed as domestic genre scenes or usurped by painted still lifes, landscapes, and seascapes. In contrast, classicism harks back to Greco-Roman antiquity and strives for simplicity and harmony, but also monumentality and grandeur. All of this is far removed from the daily life that in the Republic was so often immortalized in paint.

The prevalence of everyday life in the art of the Golden Age should, however, be qualified. Greco-Roman antiquity was, in reality, an important influence within the seventeenth-century Dutch Republic and often eclipsed the representation of daily life in painting, architecture, and the theatre. One of the most pre-eminent examples of classicism is the mid-century Huis ten Bosch, which was designed by Pieter Post as a retreat for Amalia van Solms, wife of the stadholder Frederick Henry (Figure 16.1). ${ }^{1}$ Hailed both at home and abroad, the commission conferred a semi-regal aura upon the House of Orange. The English envoy Samuel Pepys claimed that the central space, known as the Orange Hall, was the most impressive painted room that he had ever seen. The chamber, which is shaped like a Greek cross with truncated arms,

This chapter is the result of research that was undertaken within the framework of the ERC Starting Grant programme, 'Elevated Minds: The Sublime in the Public Arts in Seventeenth-Century Paris and Amsterdam'. I would like to thank Caroline van Eck, Art Di Furia, Mieke Kolk, Koen Ottenheym, and Bram van Oostveldt for their comments on earlier versions. 


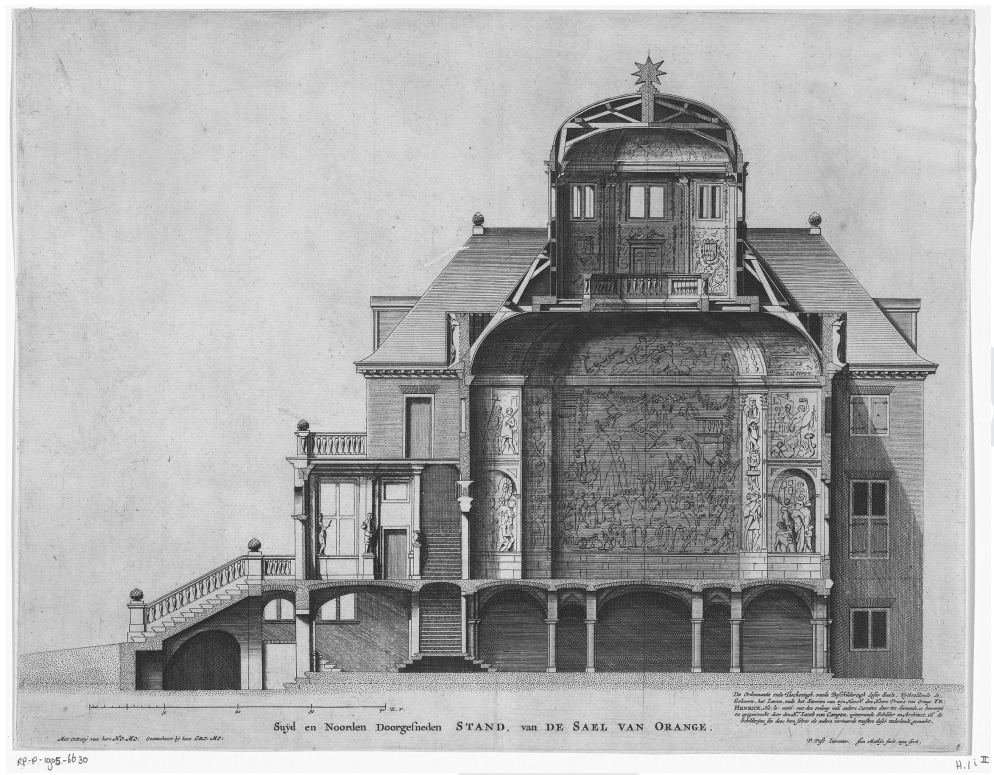

Figure 16.1

betrays Post's interest in the work of Italian architects such as Palladio and Scamozzi who, in turn, worked from the Roman architectural treatise of Vitruvius.

The Orange Hall was dominated by thirty monumental paintings that, in their historical, allegorical, and mythological subjects, glorified the life of Frederick Henry. Pieter de Grebber, Gerard van Honthorst, and Salomon de Bray were among the painters commissioned (Figure 16.2). While some of these names might now seem obscure, especially when compared with Rembrandt, Vermeer, Steen, and Hals, they were all considered to be eminent artists in their day. Their works for the Orange Hall were simply framed and arranged to form a visual whole that left viewers under the impression that they shared time and space with the gods, heroes, and allegorical figures depicted on the surrounding walls.

However, the visitors were not urged to lose themselves entirely in the dream of being immersed in a distant past, since they had to relate the awe-inspiring hall to the Oranges from the recent past and the present. The hall had to make them fully aware that thanks to the 


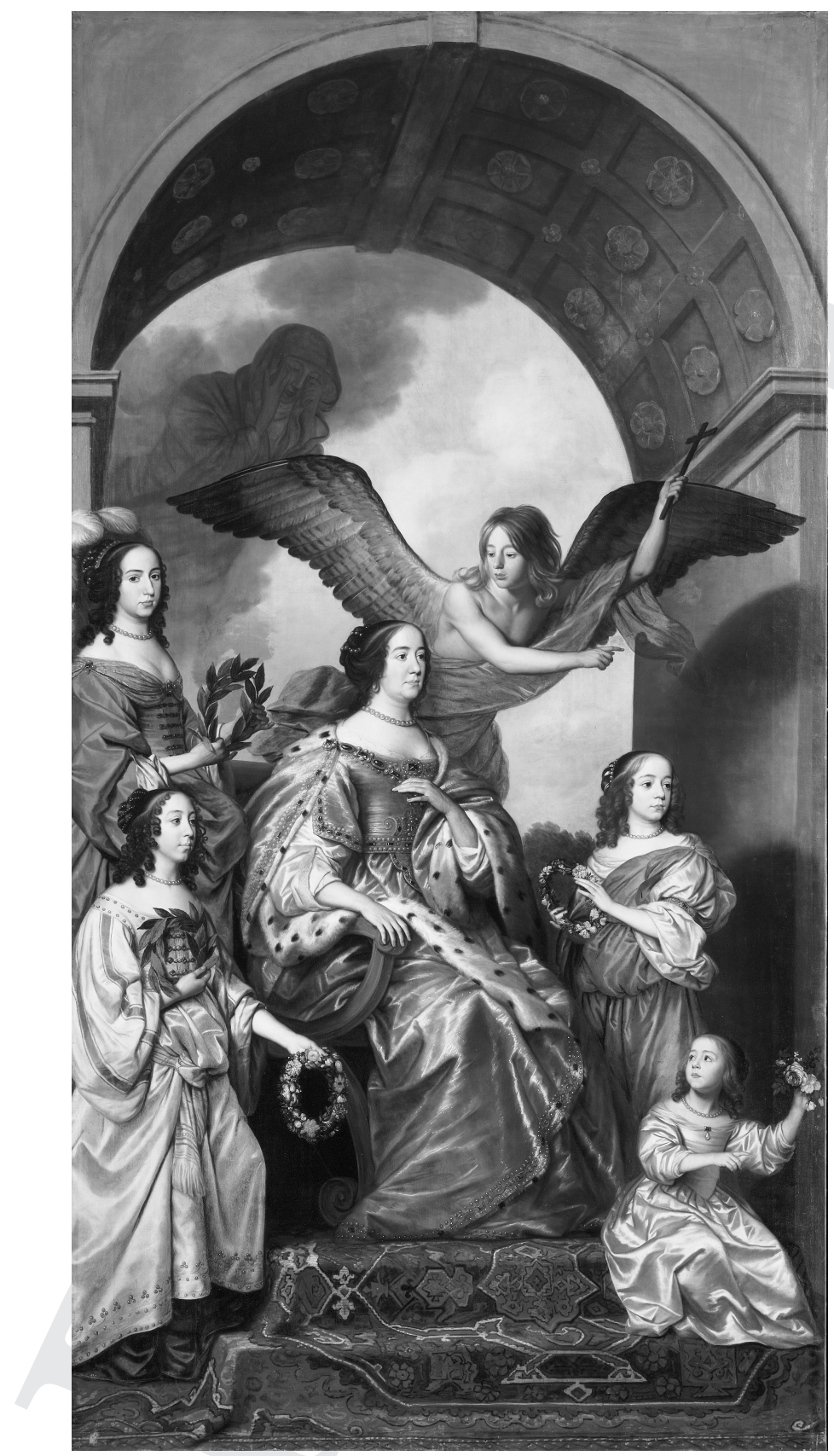

Figure 16.2 


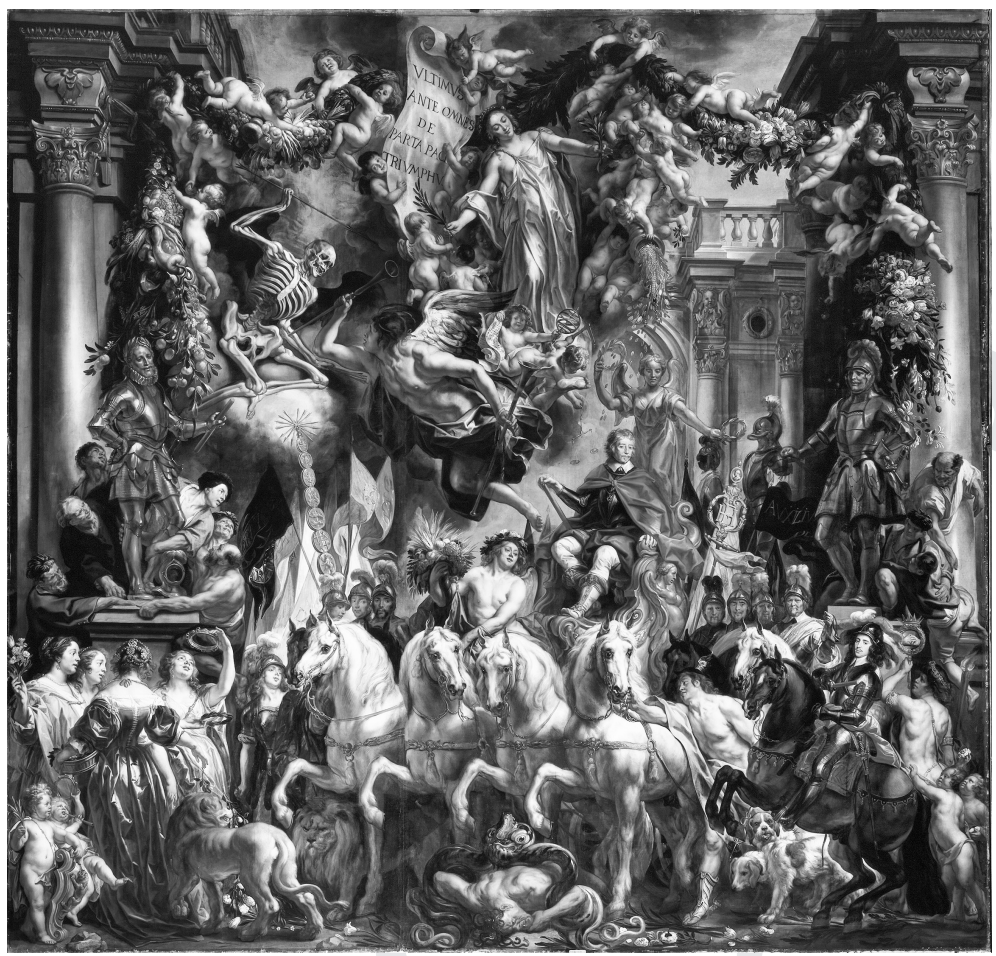

Figure 16.3

proficient and wise leadership of the Oranges the Republic enjoyed an economic and scientific as well as an artistic blooming comparable to the most prosperous periods in antiquity. Next to the Oranges, the city governments patronized art and architecture that referred to the Greco-Roman era serving a similar political agenda. Several magnificent buildings with large-scale paintings had to make manifest the florescence which the competent rulers had made possible.

Besides the political importance of referring to antiquity, the Orange Hall clarifies that in these grand undertakings a strict unified style was seldom at stake. Paintings that modern art historians would refer to as 'classicist' on the basis of their balanced compositions, vivid colours, and clarity of action were hung next to a 'Baroque' masterpiece by Jacob Jordaens that depicted Frederick Henry as a Roman triumphator (Figure 16.3). Unlike the majority of paintings in the room, this latter canvas is 
characterized by an abundant use of colour, heterogeneous figures, and an intensely dynamic composition. The juxtaposition of such divergent works highlights one of the key issues surrounding the use of the terms 'classicist' and 'Baroque'. Indeed, in the seventeenth century very little differentiation was made between the two and, furthermore, both styles were simultaneously amalgamated into one grand and immersive environment. Within this, the aforementioned paintings could be apprehended as an immense trompe-l'oeil.

Modern scholarship, in the history of art as well as in the histories of architecture and the theatre in the seventeenth-century Dutch Republic, uses fixed criteria for the formal analysis of surviving artworks, buildings, and plays. In stark contrast to the Orange Hall and observers such as Pepys, it attempts to differentiate classicism from, among other things, the Baroque. The concept of classicism, therefore, is a modern invention as much as a historical phenomenon. As a result, different disciplines vary greatly in how they apply the term 'classicism'. Art historians, for example, begin with the paintings of Hendrik Golzius and end with Gerard Lairesse. ${ }^{2}$ The classicist period therefore spans more than a century. Architectural historians limit themselves in time and space, however, and focus on the designs and buildings by Jacob van Campen and his circle, which date from the period between 1630 and 1680. ${ }^{3}$ They would define this as 'Dutch classicism'. Theatre historians, in turn, prefer the phrase 'French classicism' and home in on the last quarter of the seventeenth century - in other words, the era in which rigorous interpretations of Aristotle's and Horace's Poetics by French playwrights and theorists, such as Pierre Corneille and François Hedelin d'Aubignac, infiltrated the Republic through the literary society Nil Volentibus Arduum. ${ }^{4}$

Scholarship outside the Dutch realm has been marked in the past few decades by an ever increasing awareness that classicism can be approached as a broad intellectual movement that sought direction from the ancients in its search for a footing from which to discuss, evaluate, praise, or condemn art, architecture, and theatre..$^{5}$ This search culminated in the Querelle des anciens et des modernes, which erupted in France, in 1687, and which centred on the issue of whether the achievements of the seventeenth century surpassed those of antiquity. Modernes, such as Charles Perrault, honoured Louis XIV by formulating a positive riposte to the question and, in so doing, propelled the king's magnificent artistic, theatrical, and architectural projects forwards; anciens, such 
as Nicolas Boileau, took the opposite point of view. In later historical research, the anciens were therefore considered to be 'classicists'. These were the figures who viewed the ancient past as being superior to their own epoch and revered the rules that had been passed down from antiquity. Recent scholarship, by contrast, has considered the Querelle itself to be 'classicist'. The entire debate showcased the centrality of the classical world as a reference culture.

Parallel to the recent research into the Querelle, this chapter regards the seventeenth-century debates about art, architecture, and theatre in the Dutch Republic as 'classicist', since at the heart of these disputes lay the extent to which the ancients bequeathed appropriate measures by which to create and evaluate art. These debates were at least as numerous as in France and were the result of international exchange thanks to intense travelling and exchange of letters. They concentrate on topics as diverse as the creativity of dealing with classical orders (the distinctive proportions and designs in Greek and Roman architecture), the preference for imitation of the ancients over nature, and the usefulness of the ancient critique regarding the visualization and performance of violence. In the Dutch Republic this debate was extremely fierce even at the very start of the Golden Age.

\section{The Republic and the Ancients}

There were no ancient buildings to admire within the Dutch Republic and examples of classical sculpture were rare before the eighteenth century. Dutch architects and artists who wanted to imbibe the style of the ancients either relied on prints of antique buildings and sculptures or undertook cultural expeditions to the south. Parallel to, and partly in dialogue with, this artistic discovery of ancient aesthetics, a theoretical and philological debate ensued on how to understand and apply ancient norms and practices. Like other Europeans, the Dutch conducted intense debates about which of the ancient authors could act as an authority. The issue was not so much which of the ancients were most important in their own time (which is how we normally look at history), but how relevant they were to the new epoch. The question about antiquity's right to exist in modern times was accompanied by another enquiry, one that upended the logical pattern of thought, as contemporaries asked: who among the moderns could match the ancients? 
Here, it was a case of seventeenth-century architects, artists, and writers seeking to secure their legitimacy with the support of their classical forefathers.

In the early Golden Age, classical authors were also used as an excuse to break with the art of the previous generation, such as the elaborately decorated buildings by Lieven de Key, the brightly coloured altarpieces and muscular figures painted by Cornelis van Haarlem, and the plays of the rhetoricians (rederijkers) that were riddled with complex allegories and plot twists. The younger generation reproached their predecessors for being overly preoccupied with superfluity in both word and image, which made it impossible to attain the correct proportions and clarity. These accusations triggered a renewal movement that, in addition to the trompe-l'oeil of the Orange Hall, also paved the way for, among other things, the Amsterdam Town Hall designed by Jacob van Campen and tragedies such as Vondel's Lucifer. At the same time, the reception of the ancient authors ensures that works that we never would deem to be classicist on the basis of a formal analysis - such as the bloodthirsty play Aran and Titus (1641) by Jan Vos or Rembrandt's strikingly realistic nudes - can be evaluated. On the basis of antique texts, these works were repeatedly condemned, but also fervently defended.

In addition to the question of which of the ancient texts were most relevant to modern times, there was the issue of how best to use them in the development of standards by which to create and evaluate art. This also applies even to the greatest masterpieces of the Golden Age, such as Vondel's tragedies, Rembrandt's paintings and etchings, and the architecture of Van Campen. In the seventeenth century, the query arose as to how competently artists such as Vondel, Rembrandt, and Van Campen treated, or even surpassed, the ancients. The answer was almost never unanimous: the correct application of the rules was open to debate, and as a result the regulations were far from definitive. Just as ancient texts were typically interpreted in a multitude of different ways, a wide range of ancient authors came to be cited as authorities.

\section{Imitation or Denunciation}

As early as the beginning of the sixteenth century, Erasmus encouraged people to read as many of the ancient authors as possible and, at the same time, cautioned against following them too literally. He pointed 
out that it was necessary to adapt their work so that it could be put to the best possible use in the modern age. Erasmus launched a fierce attack on the so-called Ciceronians - a group of orthodox humanists who rigorously followed Cicero's language - for allowing Latin to become a dead language that was no longer suited to the expression of modern thought. ${ }^{6}$ To explain how the ancients ought to be followed, therefore, he provided a nuanced definition of the concept of imitatio.

The imitatio of Erasmus is anything but slavishly imitative. Those who were inspired by the ancient texts needed to always consider the degree to which the world had changed. Erasmus pointed out to his contemporaries that it was nigh on impossible to talk about the Christian faith in the language of Cicero, for the very simple reason that the Roman orator had died before the birth of Christ. If Cicero had lived in contemporary times, he would certainly have adapted his vocabulary. Such a vision of imitatio fell between two antithetical positions. At one extreme, there were those who consciously overlooked, or even completely excluded, the modern world in their orthodox imitation of the ancients. At the other end of the spectrum were those who possessed an unshakeable faith in the contemporary era.

While the Golden Age was marked by an incessant process of compromise between the two extremes, it is surprising to note how often a belief in the modern epoch was professed. Authors of all descriptions, such as Hugo Grotius, Constantijn Huygens, and Jan Vos, wrote that the present day surpassed antiquity because of the progress that had been made in building upon, and advancing, classical achievements. Modern inventions such as the lens, gunpowder, the compass, and the printing press provided ample corroboration. The popular playwright and theatre-maker Vos came under increasingly heavy criticism for only presenting bloody spectacles but, at the same time, his explicit reference to René Descartes in the preface to Medea reveals that he was acutely aware of contemporary science. Vos viewed Descartes as the harbinger of an entirely new era, and it pleased him to think that the latter was acquiring more acolytes than Aristotle. ${ }^{7}$ Nevertheless, rather than completely abandoning the ancient texts, Vos began to analyse them for their usefulness within the current context. The quest for their continued viability was driven by historicism and by Vos' awareness of the essential differences between antiquity and the present time.

Erasmus' nuanced interpretation of the concept of imitatio thus prepared the ground for the debates about the relationship between 
antiquity and modernity that unfolded a century later in all their complexity. Another term that Erasmus addressed was the religious concept of the 'heretic'. The scholar revealed, with some derision, how the Ciceronians had appropriated the term 'heretic' and utilized it within a literary context to identify writers whose work deviated from the strict rules governing imitation. ${ }^{8}$ This behaviour particularly aggrieved the orthodox humanists who fired harsh salvoes at those writers who refused to follow their conventions. The appropriation of the term 'heretic' thus enabled the formulation of general rules by which to roundly condemn all forms of aberration. While Erasmus mocked the Ciceronians for their use of the highly charged term, he also conceded that some considered the 'heretic' label to be a badge of honour. Those who did not wish to abide by the prevailing rules took pride in being thus stigmatized.

\section{Classicism in Architecture}

It is remarkable how often the term 'heretic' was used in the Netherlands. What started life as a deadly sobriquet used against the Protestants was soon commandeered by the Protestants themselves, and with just as many far-reaching consequences. It is therefore very surprising to note how, at the very dawn of the Golden Age, the term was appropriated and used in the discourse about art. Karel van Mander, for example, employed the word in his descriptions of various building practices. In his Schilder-Boeck of 1604, the father of Dutch art history described the newly completed Vleeshal (Meat Hall) by Lieven de Key in Haarlem as an indication of the 'the serious heresy [that] has occurred in masonry, with a great frenzy of ornaments ... very disgusting to see' (Figure 16.4). ${ }^{9}$

Van Mander discusses De Key's 'heresy' within the context of the ancient architectural dictums and Italian building practices and, in so doing, arrives at a nuanced image of the correct form of imitatio. ${ }^{10}$ The Haarlem connoisseur also condemned De Key for his many variations of the ancient column orders and their fragmentation. He judged the ornate gables of the Vleeshal, which were covered in scrollwork and obelisks, to be an eyesore for being at too much a variance with the Greco-Roman model. By contrast, Van Mander paid homage to the style of Italian architecture that meticulously referenced, but did not 


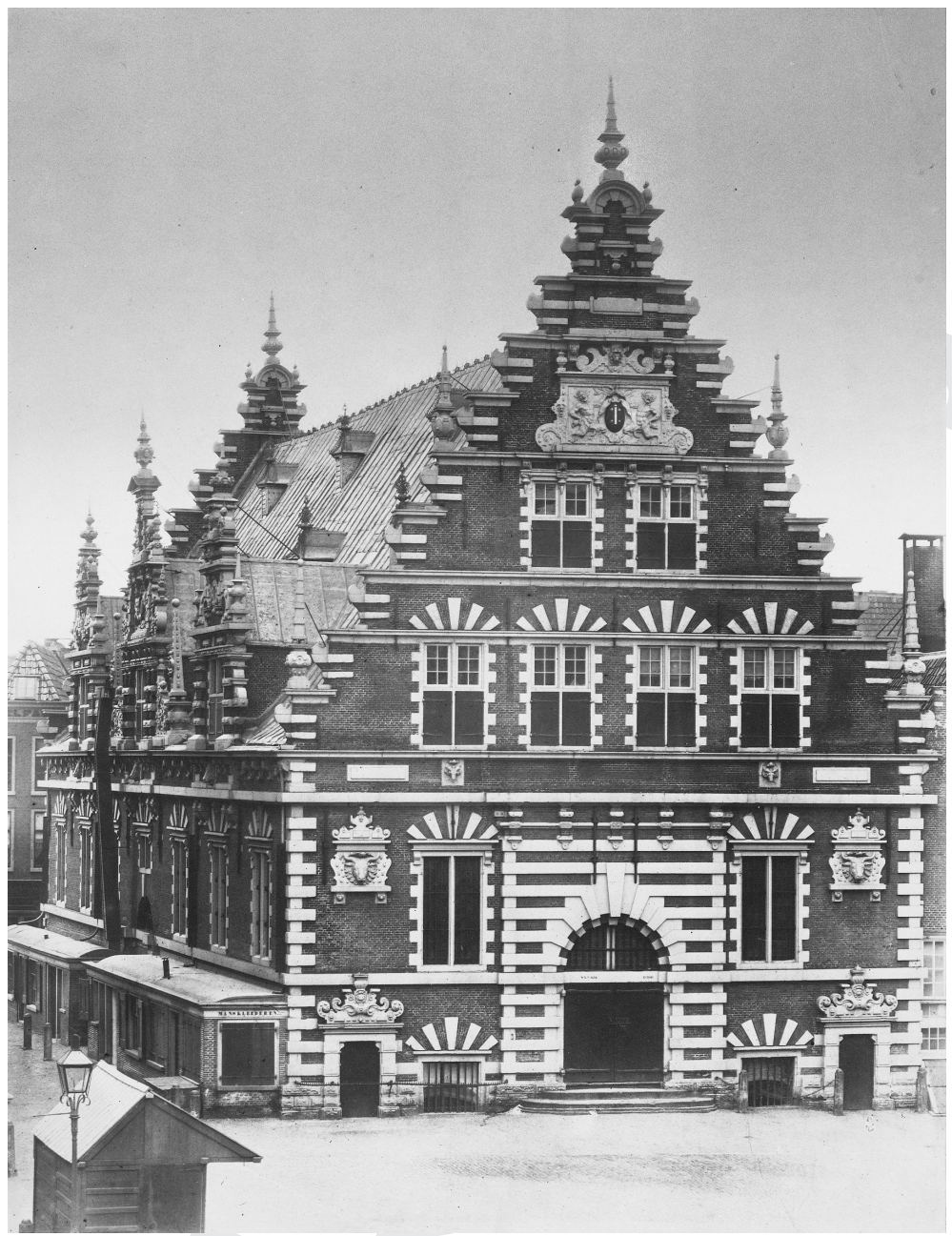

Figure 16.4

slavishly imitate, classical buildings. He mentions Michelangelo immediately after Vitruvius, and states that the Italian was able to perfectly apply, and even successfully vary, the ancient orders:

In architecture beside the old common manner of the ancients and Vitruvius he [Michelangelo] has brought forth other new orders of cornices, capitals, bases, tabernacles, and other ornaments, wherefore all architects that follow after owe him thanks for his having freed 
them from the old bonds and knots, and given them free rein, and licence to invent something besides the Antique. ${ }^{11}$

Working half a century earlier than Van Mander, Pieter Coecke van Aelst introduced Vitruvius into Dutch culture through his translation of Sebastiano Serlio's treatise on architecture. ${ }^{12}$ Long after Van Mander, the Italian guidelines continued to serve as the model of how Vitruvius' treatise could be used in modern construction practices, and they remained current throughout the entire seventeenth century. As the era progressed, however, increasing emphasis was placed upon ideal proportions. Scamozzi's L'idea delle architettura universale (1615), which had triumphed in clarifying the rules of harmony laid down by Vitruvius in De Architectura, was consequently considered to be an authority by Van Campen's circle. The treatise was founded upon the circle, square, and rectangle, with the ratios of 2:3, 3:4, 3:5, and 1:2. The practical application of the principles, however, was the subject of ongoing debate. Constantijn Huygens' home in The Hague (demolished in 1875) was a pre-eminent example of how the theory was put into practice. ${ }^{13}$

During his diplomatic travels on behalf of the House of Orange, Huygens had developed a passion for the villas and palaces built by Andrea Palladio in and around Venice, and also for the Queen's House and the Banqueting House designed by Inigo Jones in London. He was determined to familiarize his countrymen with the architectural power, simplicity, and splendour that could be derived from harmonious proportions and the ingenious application of the ancient orders. Huygens strove to fulfil this ambition by building his own house in the centre of The Hague, which he designed with his friend Jacob van Campen. It was an achievement of which Huygens must have felt proud, for he disseminated the plans as engravings (Figure 16.5). The print of the front façade reveals that a clean sweep was made of the lush decorations that De Key had deployed. In Huygens' design, there is no imaginative handling of the classical orders, nor stepped gables with scroll work and obelisks. The building relies, instead, upon the sparing use of antique pilasters, cornices, pediments, and garlands. It is precisely this simplicity that lends the façade a monumental appearance and ensures that the eye is drawn towards the three figures on the central pediment. The façade is adorned by sculptures representing Firmitas (Strength), 


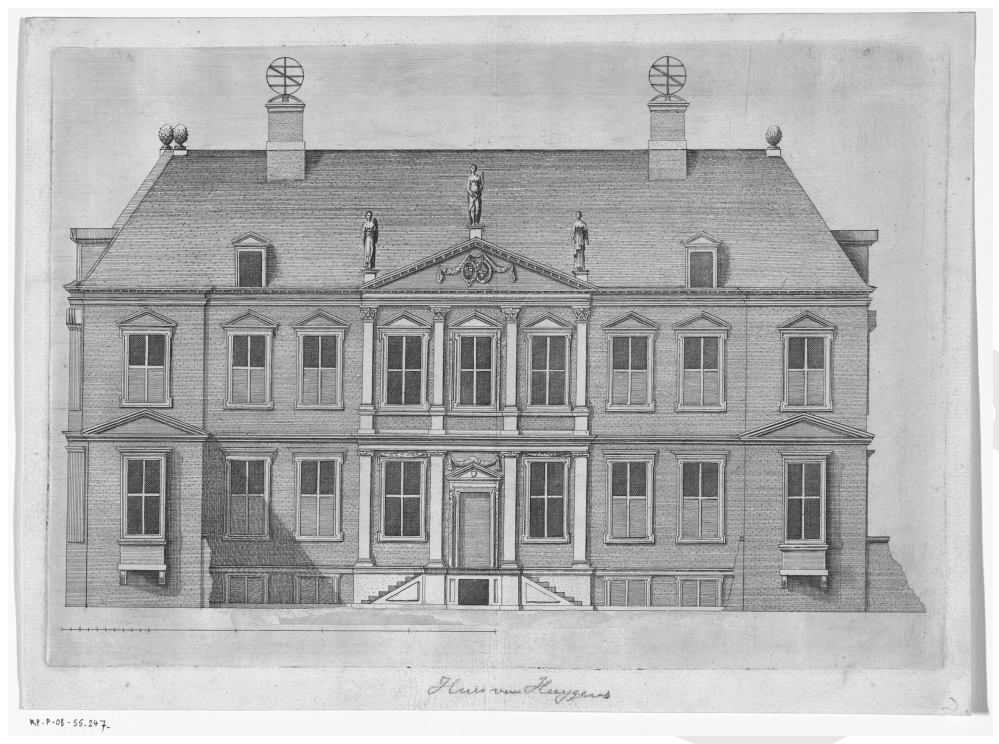

Figure 16.5

Utilitas (Utility), and Venustas (Beauty), the three principal architectural virtues as elaborated by Vitruvius.

Huygens, who sent copies of the engravings to the much-admired Inigo Jones, among others, wrote to a friend:

I have built a house, had prints made of it and will send them to you; Inigo Johns [sic] will see that his manner does not differ much from this one ... Mr Inigo Jones will be able, if he pleases, to learn that the good Vitruvius is not totally excluded from Holland. ${ }^{14}$

We do not know whether Jones reacted to the engravings or had an opinion about the building. Not everyone, however, was convinced that Huygens' design had succeeded in importing Vitruvius to the Netherlands. It was Rubens, no less, who exhorted Huygens to think again. The Antwerp master wrote to Huygens that, while the design was indeed meritorious, it failed to reveal the proper application of the Vitruvian rules on proportion. ${ }^{15}$ If we stand before a seventeenth-century building today, one that betrays scrupulous proportions, obviously imitative antique column orders, and a lack of superfluous decoration, we would immediately label it 'classicist'. Yet Rubens' reaction to 


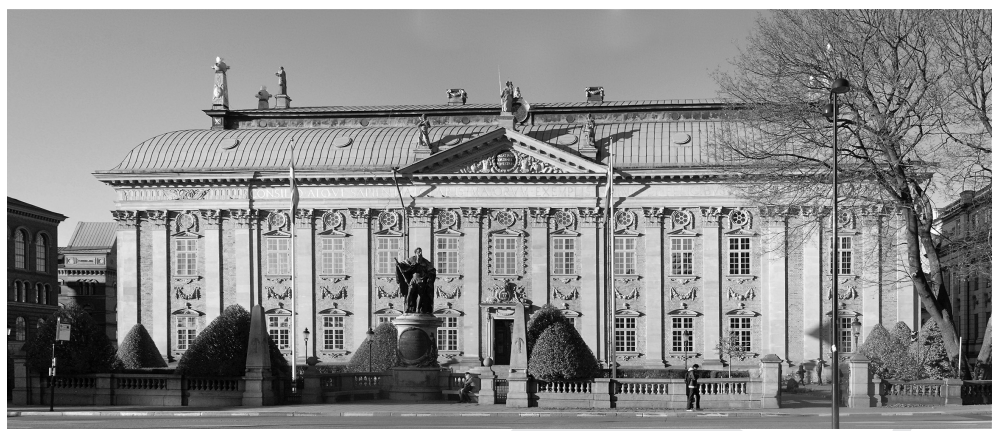

Figure 16.6

Huygens' home clearly indicates that in the seventeenth century, the label 'classical' was not given lightly and was ever subject to negotiation.

Despite Rubens' qualms, Huygens' interpretation of Vitruvius in the following decades led to the establishment of 'Dutch classicism'. One of its most impressive examples is the Amsterdam Town Hall by Jacob van Campen (Figure 12.2). The building's fame was bolstered by the many visitors who extolled its harmonious and majestic appearance, and the countless paintings and prints that served to emphasize the grandeur of the edifice. An impressive number of eulogies further augmented the allure of the building within the Dutch Republic. Dozens of seventeenth-century writers, including Huygens, Vondel, and Vos, took the Town Hall as a subject and were rewarded for their efforts by the city mayors. ${ }^{16}$ Never before had so many poems - either during or immediately after construction - been written about a building. Most of the panegyrists also argued, therefore, that the Amsterdam Town Hall triumphed over the ancient architectural traditions, and repeatedly referred to it as the eighth Wonder of the World. The seven ancient buildings and colossal sculptures - which had long since disappeared or were no longer observable - were anything but; instead they were manifestations of an ancient theory that claimed the overwhelming effect as the ultimate goal.

Thanks to, among other buildings, the Amsterdam Town Hall, Dutch architecture became more and more influential throughout northern Europe as the seventeenth century advanced. The spread of 'Dutch classicism' was accomplished by travellers, through illustrations of representative examples, and also by Dutch architects who worked on 
commission in other lands. ${ }^{17}$ Justus Vingboons, for example, was invited to Stockholm in 1653 for the construction of the parliament, the Riddarhuset (Figure 16.6). For this commission he relied upon the rejected design that his brother, Philips, had made for the Amsterdam Town Hall and which had been issued as prints. Again, the pilasters dominate the façade of the imposing building, and the decoration is limited to garlands and three figures on the central pediment. In addition to the Riddarhuset, countless other governmental buildings, houses, villas, and palaces in northern and eastern Europe were designed by architects from the Dutch Republic or were inspired by their designs. Across the Baltic, in Sweden, Brandenburg, and the Polish-Lithuanian kingdom, Dutch classicist architecture was imitated to the extent that entire Dutch-looking streets and neighbourhoods emerged. Even in England, the work of Dutch architects and the proliferation of architectural prints substantially increased the impact of Scamozzi and Jones after the restoration of the monarchy in 1660. Disparaged by Rubens, Huygens' interpretation of the classics had, after all, been elevated to a European trademark.

\section{Classicism in Drama and Theatre}

While the application of classical theory fuelled debate within the context of seventeenth-century architecture, the authority of Vitruvius was more or less fixed. This was not the case in the theatre, where more classical authorities and models were available, whose validity and relative worth was questioned. Moreover, we can speak of a real clash between theory and practice. The ancient authoritative texts of Aristotle and Horace, in themselves hardly unambiguous, were soon challenged by English and Spanish theatrical practices and theories, which travelled to the Dutch Republic. Referencing Philip Sidney and Félix Lope de Vega, Theodore Rodenburgh applied English and Spanish theatrical theory as early as $1619 .{ }^{18}$ The ancient poetics encountered at least as much resistance from the makers of Senecan horror pieces, among others Jan Vos and later Thomas Asselijn. The discussions about the importance of Aristotle and Horace versus Seneca also had a direct impact upon parallel discussions within the context of the visual arts. 
Theatre historians have paid a great deal of attention to the introduction of the French classicist rules by the members of the Nil Volentibus Arduum society, which was founded in $1669 .{ }^{19}$ The circle has been repeatedly credited with the importation of French theatre theory and practice into the Republic, most notably Pierre Corneille's requirement for unity of time, place, and action in the tragic plot, as well as the concepts of vraisemblance (credibility) and bienscéance (propriety). The importance of Nil should be qualified on two important counts, however. Firstly, the Aristotelian and Horacian rules which Corneille applied had been known in the Republic from the early seventeenth century, long before the foundation of Nil. Secondly, the influence of Nil's classicism was limited to a relatively small section of the Dutch theatrical world; an important part of theatrical practice simply ignored the ancient rules and their French classicist interpretation until the end of the seventeenth century, despite the frantic efforts of the society.

The development of rules based upon the work of Aristotle and Horace followed a tortuous path. The French theorists and playwrights who were so influential in the second half of the century had themselves been deeply influenced by Dutch humanists such as Daniel Heinsius and Gerardus Vossius and their interpretation of the ancient poetics, especially those of Aristotle. Heinsius' De constitutione tragoediae of 1611 rapidly gained a reputation in northern Europe as the synthesis of the study on Aristotle's poetics. Heinsius influenced, among others, the French theatre theorists Chapelain and La Mesnardière who, from their position within the Académie française, gave form to French classicist drama. The two main proponents of French classicism, Corneille and Racine, were also heavily influenced by Heinsius. Corneille mentions the Dutch writer in the preface of Menteur (1644) as follows: 'the celebrated Heinsius who not only translated Aristotle's Poetics but also wrote a treatise on the constitution of tragedy'. Likewise, the international influence of Vossius' Poeticae Institutiones of 1647 on the foundations of French classicism should not be underestimated.

Heinsius and Vossius not only influenced French theatre practices but also had important links with the pre-1669 Dutch theatre world. Vondel, for example, began using the poetics of Heinsius and Vossius in the application of the Aristotelian and Horacian dramatic rules at the beginning of the 1640 . A meticulously conceived plot structure became increasingly important to the dramatist, and his experimentation with 
this aspect of the play is clearly articulated in Jephtha (1659). Here, Vondel makes his first explicit reference to unity of action while allowing the plot shift (peripeteia) and the protagonist's sudden insight into his or her situation (agnitio) to shine as the crown jewels of the tragedy. Furthermore, Vondel also follows Horace as a guide to ensuring credibility (or what is known in French theatre theory as verisimilitude). He does not kill Jephta's daughter before the eyes of the audience because, to use his own words, it was an impossible feat that lacked plausibility. A decade later, the argument concerning credibility was still current, and was further fuelled by Nil's advancement of the notion of propriety (bienscéance) as part of its explicit prohibition of violence within theatrical performances.

While the introduction of Aristotelian and Horacian rules for dramatic texts is therefore difficult to separate out from the theatrical performance itself, it is a mistake to assume that the visual aspect of the presentation became increasingly less important as the century progressed. Vondel was particularly committed to optimizing the impact of the performance and regularly worked with Jan Vos. ${ }^{20}$ As head of the Amsterdam Theatre, the latter attempted to augment the power of Vondel's tragedies by including tableaux vivants and dances, among other things. Despite the efforts dedicated to making these plays a success, however, the Aristotelian and Horacian restrictions weighed heavily and, over time, the titles slipped out of the repertoire. Spectacular theatre in the tradition of Seneca, Lope de Vega, and Calderón, but also the Italian and French pièces à machines, won the day. To accommodate such productions, the Amsterdam Theatre was completely rebuilt in 1667 , with Vos confidently asserting: 'The seeing comes before the saying. ${ }^{21}$

In his preface to Aran and Titus (1641), the most successful theatre performance of the Golden Age, Vos highlighted the correspondences between his own work and the tragedies of Vondel. ${ }^{22}$ The relationship of his gory spectacle to the plays of the latter is one of symbiosis. Whereas the tragedies of Vondel showcase the inherent goodness in mankind, Vos reveals the fundamental weakness of humanity, and the shadowy dimension filled with cruelty and egotism. It is clear that Vos does not consider the two perspectives to be mutually exclusive. However, instead of the dramatic theories derived from Aristotle or Horace, Vos gravitated towards the work of Seneca. In the foreword that he wrote for his Medea (1667), he vigorously defends his choice and compares himself 
with none other than Phaethon. ${ }^{23}$ Just as the mythological boy challenges Apollo, Vos dares to surpass Aristotle and Horace by calling them into question, although he does not suffer Phaethon's fatal fall.

Vos, in his own words, could avoid ruination only by remaining resolutely within the here and now and by assessing every rule prescribed by the ancients for its usefulness within contemporary theatrical practice. Nowhere else is the imitatio of antique theory so sharply questioned in the Dutch Golden Age. Vos did not so much sweep the rules of Aristotle and Horace from the table, but rather subjected them to intense scrutiny. Thus Vos counters Horace's requirement for credibility

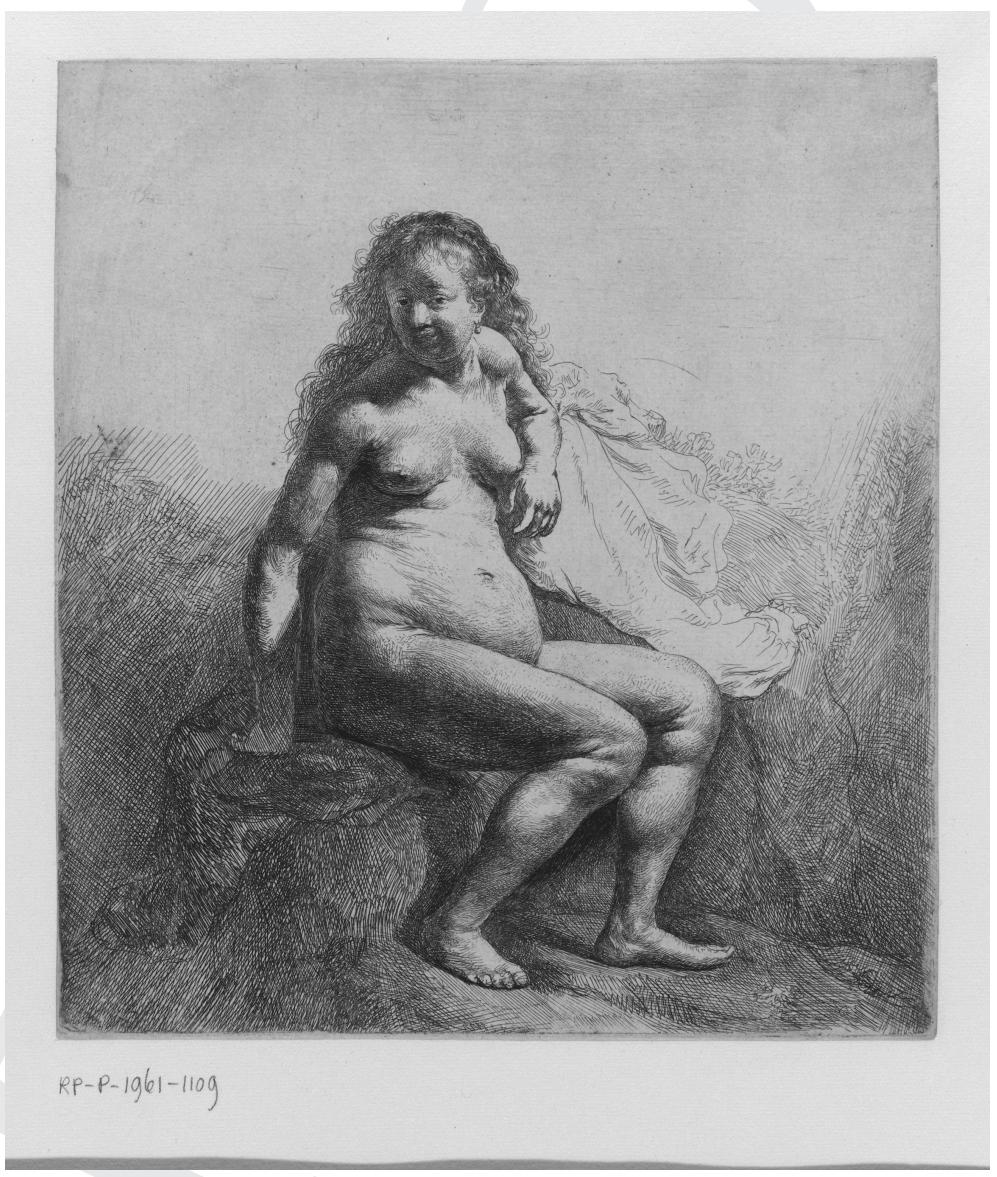

Figure 16.7 
through historicization. The playwright upholds the rule of credibility because he believes that his audiences also need to be convinced of the dramatic scenes that unfold before their eyes - an essential requirement if they are to be swept away by the action. Yet Horace's conclusion that violence should not be portrayed, however, is seen as being applicable only to antiquity, the grounds for this being that Roman audiences would have been slow to accept the veracity of staged violence on account of their constant exposure to the savagery of the amphitheatres. The fact that the Dutch public was unfamiliar with the performance of a similar type of violence, and the ingenious illusions that could be quickly achieved in the new Amsterdam Theatre, were just two of the reasons why the public clamoured, according to Vos, to see his Medea hurl her children to earth from her flying chariot.

Whereas Vos and Vondel were mutually respectful of each other's work and occasionally collaborated, the gulf between the proponents of the strict application of the Aristotelian and Horacian rules and those who championed the spectacles inspired by Seneca widened ever further during the subsequent generation. The battle was fought on a knife edge, but often within the same parameters. Both sides accused the other of the self-same behaviour: slavish imitation. Members of Nil Volentibus Arduum referred to one of their most ardent opponents, Thomas Asselijn, whose plays required gory performances on stage, as an ape of Jan Vos. Asselijn, in turn, likened the members to infants who clung to chairs and benches in order to toddle a few steps. The word 'heretic' swung back and forth like a pendulum. It was Asselijn who used it as a nickname for his own performances when comparing members of Nil with the Inquisition: 'or a slavish probe of Art; wherein everything (which does not correspond with the canon or the rule of the Concilium) is seen as a heresy and rejected'. ${ }^{24}$

\section{Rembrandt}

Seventeenth-century thinking on the correct application of ancient rules did not necessarily confine itself to a single art form. Nil Volentibus Arduum, for example, did not limit its critiques to the theatre: it criticized Rembrandt's oeuvre in the same terms as Asselijn's drama. In Gebruik én misbruik des tooneels (Use and Misuse of the Theatre, 1681), a plea for French classicism in the theatre, leading 
member of Nil, Andries Pels, offered Rembrandt's nudes up for discussion. Pels considered Rembrandt to be the first heretic within the field of painting. ${ }^{25}$ Rembrandt is known as a master at depicting postures and in the use of colour, but also as someone who took his lead from nature and observed it meticulously, as his unashamed nudes make clear (Figure 16.7):

Whenever he would paint a nude, as sometimes happened, He did not choose a Greek Venus as his model; But rather a laundress, or a turf stamper from a shed, Calling his aberrance imitation of Nature.

Here we see actual works of art from antiquity being used to reinforce the ancient theory. Pels acknowledges the imitatio of antique examples the sculptures of Venus - and weighs these against the painting of an ordinary woman. He condemns the fact that Rembrandt simply picks his subjects from everyday life, which he strives to render as faithfully as possible. For this condemnation he explicitly refers to the Horacian and French classicist rules of propriety. The poetic term used to criticize the atrocities and depravities within the theatrical world is now used in a discourse about art (in doing so, Pels was echoing Van Mander, who had also argued against the overtly faithful representation of nature as early as 1604 in his criticism of Caravaggio). ${ }^{26}$ Pels portrayed Rembrandt as an innovator and, to ensure that this would be properly understood as blame rather than praise, he used the expression 'first heretic'.

In his scathing attack on Rembrandt, Pels also attacked the artist's supporters, such as Samuel van Hoogstraten. In his writings on art, this pupil of Rembrandt broke with the paintings and prints of, among others, Golzius and Cornelis van Haarlem (which were later grouped under the heading of 'Haarlem Mannerism') and opted to honour the painterly technique of his master. Van Hoogstraten warns against the overly free invention of the Haarlem artists and condemns depictions that rely too heavily upon the idealizing eye of the painter and too little upon the observation of nature. ${ }^{27}$ This leads him, ultimately, to argue that it is far better to imitate nature than the work of the ancients. Once again, the term 'heretic' is invoked: 'Even following the ancients has brought some to heresy. ${ }^{28}$ Van Hoogstraten does, however, believe that artists could nevertheless follow their antique counterparts without falling prey to heresy. To support his argument, he refers to the Greek artist Amphiaraos who painted horses covered in dust and sweat: 'which 
slightly diminished their beauty but nevertheless gave them a greater appearance of truth' ${ }^{29}$

It is precisely this conviction, according to Erik Jan Sluijter, that may have encouraged Rembrandt's determination to paint such realistic nudes. ${ }^{30}$ The master does not deviate from antiquity; he simply chooses to ignore the Horacian concept of decorum, or decency. Instead, he decides to follow an alternative ancient dictum, namely that which elevates realism over ideal beauty. Thus Rembrandt was pitched against his Italian counterparts, such as Raphael, and Dutch colleagues, such as Golzius, who believed in idealism. Rembrandt deliberately took an alternative path, therefore, and selected his own ancient authorities. The artistic revolution that he triggered - dramatic as it was - can therefore be interpreted from the etymological origin of the word, namely revolvere, which means 'return'. Rembrandt thus looks backwards in order to innovate and securely anchors his radical decision in the depths of history.

\section{Conclusion}

On the basis of seventeenth-century debates, this chapter has shown that classicism within the Dutch Republic was Janus-headed. The concept of being 'classical' was shaped by constant negotiation over the way in which retrospection might lead to progress. No matter how impatient some of the progressive interlocutors revealed themselves to be during such deliberations, they all tended to believe that retrospection was invariably productive. Architecture, art, and theatre remained, therefore, firmly tethered to ancient theory. Today, such an historically oriented view of the future is difficult to grasp. We are profoundly influenced by a belief in progress that regards the past as a permanently closed chapter. This stance originated in the Enlightenment and was widely disseminated during the French Revolution. During this period, neo-classicism was revered throughout Europe. Despite the influence of classicism on neo-classicism, there is a substantive difference between the two movements. This stems not only from the changing sense of historicity but also from the fact that the appropriation of the ancients was anathema to neo-classicists. While seventeenth-century artists sought a means by which to enable the ancients to advance into their own time, neo-classicism was characterized by a sense of irrevocable 
loss. This precluded appropriation, and it was only possible to reference, and this in the most literal way, antiquity. The Janus head that had been so fiercely determined by classicism was, at that moment, lost forever.

\section{Notes}

1. M. Van Eikema Hommes and E. Kolfin, De Oranjezaal in Huis ten Bosch. Een zaal uit loutere liefde, Zwolle, 2013.

2. A. Blankert, 'Classicisme in de Hollandse historieschilderkunst', in A. Blankert (ed.), Hollands classicisme in de zeventiende-eeuwse schilderkunst, Rotterdam, 1999, 12-33.

3. K. Ottenheym, 'Proportional Design Systems in Seventeenth-Century Holland', Architectural Histories 2 (2014), 1-14.

4 A. J. Gelderblom, 'Een verjongend corset: het literaire classicisme in de Republiek', in Blankert (ed.), Hollands classicisme, 54-63.

5. M. Fumaroli, 'Les abeilles et les araignées', in A.-M. Lecoq (ed.), La Querelle des anciens et des modernes, Paris, 2001, 7-218.

6. G. W. Pigman, 'Imitation and the Renaissance Sense of the Past: The Reception of Erasmus' Ciceronianus', Journal of Medieval and Renaissance Studies 9 (1979), 155-77.

7. J. Vos, 'Aan de beminnaars van d'oude en nieuwe tooneelspeelen', in J. Vos, Alle de gedichten, Amsterdam, 1662, C4r.

8. B. I. Knott, 'Introductory Note', in Desiderius Erasmus, Dialogus Ciceronianus, Toronto, 1986, 324.

9. K. van Mander, Het Schilder-Boeck, Haarlem, 1604, fol. 168v. Translation is mine.

10. K. Fremantle, The Baroque Town Hall of Amsterdam, Utrecht, 1957, 88-9; and K. Ottenheym, 'De schilder-architecten van het Hollands classicisme', in Blankert (ed.), Hollands classicisme, 39 .

11. Van Mander, Schilder-Boeck, fol. 168v.

12. H. De la Fontaine Verwey, Pieter Coecke van Aelst en de uitgaven van Serlio's architectuurboek, The Hague, 1954.

13. K. Ottenheym, Schoonheid op maat. Vincenzo Scamozzi en de architectuur van de Gouden Eeuw, Amsterdam, 2010, 6-10 and 61-106; K. Ottenheym, 'Architectuur', in J. Huisken, K. Ottenheym, and G. Schwartz (eds.), Jacob van Campen. Het klassieke ideaal in de Gouden Eeuw, Amsterdam, 1995, 157.

14. Quoted in G. Worsley, Inigo Jones and the European Classicist Tradition, New Haven, 2007, 52.

15. Worsley, Inigo Jones, 55; and K. Ottenheym, 'La vera simmetria conforme le regole degli antichi. Rubens and Huygens on Vitruvius', in K. Ottenheym and K. De Jonge (eds.), Unity and Discontinuity: Architectural Relations Between the Southern and Northern Low Countries, 1530-1700, Turnhout, 2007, 137-61.

16. S. Bussels, 'Meer te verwonderen, als immer te doorgronden. Het Amsterdamse stadhuis, een overweldigende burgerspiegel', Tijdschrift voor Geschiedenis 126 (2013), 234-48.

17. Ottenheym, Schoonheid op maat, epilogue; and W. Kuyper, Dutch Classicist Architecture: A Survey of Dutch Architecture, Gardens and Anglo-Dutch Architectural Relations from 1625 to 1700 , Delft, 1980. 
18. T. Vergeer and O. van Marion, 'Spain's Dramatic Conquest of the Dutch Republic: Rodenburgh as a Literary Mediator of Spanish Theatre', De Zeventiende Eeuw 32 (2016), 40-6o.

19. Gelderblom, 'Een verjongend corset'.

20. S. Bussels, 'Vondel's Brothers and the Power of Imagination', Comparative Drama 49 (2015), 49-68.

21. Vos, 'Aan de beminnaars', $\mathrm{C}_{3}$ r.

22. Vos, '[Dedication to Joan Huydecoper]', in Alle de gedichten, A3r-v.

23. Vos, 'Aan de beminnaars', C2v-A2r.

24. '[O]fte een slaafachtige onderzoeking der Kunst; waar by alles, (wat niet met den kanon ofte reegle van dat Concilium over een komt,) werdt verkettert, ende verworpen': N.N. [Thomas Asselijn], 'Voorbericht tegens de Dichtkunstige Onderzoekers', Koninklijke Nederlandse Academie van Wetenschappen (KNAW) G1148 Band 64, fol. 2r, quoted in Marijke Meijer Drees, 'De treurspelen van Thomas Assselijn (ca. 1620-1701)', PhD dissertation Utrecht University, 130. Translation is mine.

25. A. Pels, Gebruik én misbruik des tooneels, Amsterdam, 1681, 35.

26. E. J. Sluijter, 'Rembrandt and the Rules of Art Revisited', Jahrbuch der Berliner Museum 51 (2009), 123-4.

27. T. Weststeijn, The Visible World: Samuel van Hoogstraten's Art Theory and the Legitimation of Painting, Amsterdam, 2008, 126.

28. '[Z]elf d'Antijken te volgen heeft sommige in kettery gebracht': S. van Hoogstraten, Inleyding tot de hooge schoole der schilderkonst, Rotterdam, 1678, 18.

29. '['T] welk of het hen wel iets van de schoonheit benam, nochtans een te grooter schijn van waerheyt gaf: Van Hoogstraten, Inleyding, 168. Translation is mine.

30. Sluijter, 'Rembrandt', 121-9. 
